\title{
AMENDMENTS
}

\section{Author Correction: Retinoic acid signaling is critical during the totipotency window in early mammalian development}

Ane Iturbide, Mayra L. Ruiz Tejada Segura (D), Camille Noll, Kenji Schorpp, Ina Rothenaigner, Elias R. Ruiz-Morales (D), Gabriele Lubatti, Ahmed Agami (D), Kamyar Hadian (D), Antonio Scialdone (D) and Maria-Elena Torres-Padilla (D)

Correction to: Nature Structural \& Molecular Biology https://doi.org/10.1038/s41594-021-00590-w, published online 27 May 2021.

In the version of this article initially published, the surname of author Mayra L. Ruiz Tejada Segura was misspelled as Ruiz Tejeda Segura. The error has been corrected in the online version of the article.



Open Access This article is licensed under a Creative Commons Attribution 4.0 International License, which permits use, sharing, adaptation, distribution and reproduction in any medium or format, as long as you give appropriate credit to the original author(s) and the source, provide a link to the Creative Commons license, and indicate if changes were made. The images or other third party material in this article are included in the article's Creative Commons license, unless indicated otherwise in a credit line to the material. If material is not included in the article's Creative Commons license and your intended use is not permitted by statutory regulation or exceeds the permitted use, you will need to obtain permission directly from the copyright holder. To view a copy of this license, visit http://creativecommons.org/licenses/ by/4.0/.

Published online: 14 February 2022

https://doi.org/10.1038/s41594-022-00740-8

(C) The Author(s) 2022 